\title{
PEMANFAATAN ISI RUMEN TERFERMENTASI CELLULOMONAS $S p$ SEBAGAI CAMPURAN PAKAN KOMPLIT TERNAK KELINCI
}

\author{
Sony A.E. Moningkey*, R.A.V. Tuturoong, I.D.R. Lumenta
}

Fakultas Peternakan Universitas Sam Ratulangi Manado, 95115

\begin{abstract}
ABSTRAK
Penelitian bertujuan untuk mengetahui pemanfaatan isi rumen sapi dengan menggunakan teknik pengolahan fermentasi sehingga memungkinkan isi rumen tersebut dijadikan sebagai pakan ternak kelinci. Materi yang digunakan dalam penelitian ini terdiri dari isi rumen sapi, starter Cellulomonas sp, ternak kelinci, pakan komplit. Penelitian ini terdiri dari dua tahap. Penelitian tahap pertama menggunakan metode eksperimental dengan rancangan acak lengkap (RAL) 4 perlakuan dan 6 ulangan. Perlakuan dibagi berdasarkan lama fermentasi yang terdiri dari 0 jam, 24 jam, 48 jam dan 72 jam. Untuk penelitian tahap kedua menggunakan metode eksperimental dengan Rancangan Acak Kelompok (RAK) berdasarkan bobot badan awal dari kelinci. Perlakuan yang diberikan adalah level penggunaan isi rumen terfermentasi terbaik dalam ransum pakan komplit. Peubah yang diamati yaitu konsumsi pakan, pertambahan bobot badan dan konversi pakan. Hasil penelitian Tahap pertama menunjukkan bahwa perlakuan P4 (72 jam) sebagai perlakuan terbaik dilihat dari parameter kandungan protein kasar dan serat kasar. Hasil penelitian tahap kedua menunjukkan bahwa pemberian pakan yang menggunakan isi rumen fermentasi (IRF) dapat meningkatkan konsumsi pakan dan pertambahan bobot badan. Kesimpulan dari penelitian ini adalah Pemberian $30 \%$ campuran isi rumen
\end{abstract}

*Korespondensi(corresponding Author)

Email: sonnymoningkey@unsrat.ac.id terfermentasi Cellulomonas sp dalam pakan komplit menunjukkan hasil terbaik dilihat dari parameter konsumsi, pertambahan bobot badan serta konversi ransum ternak kelinci.

Kata Kunci: Isi rumen, fermentasi, Cellulomonas sp, pakan komplit, kelinci

\begin{tabular}{l}
\multicolumn{3}{c}{ ABSTRACT } \\
UTILIZATION OF FERMENTED \\
RUMENT CONTENT \\
CELLULOMONAS SP IN \\
COMPLETE FITED \\
MIXED FOR RABBIT.
\end{tabular}

Research conducted to learn how to use cattle rumen content by using fermentation processing techniques to enable this rumen to be used as rabbit feed. The material used in this study consisted of cattle rumen contents, starter Cellulomonas sp, rabbits, complete feed. This research consisted of two phase. The first study used an experimental method with a completely randomized design 4 preparations and 6 replications. The fermentation time consists of 0 hours, 24 hours, 48 hours and 72 hours. For the second study using an experimental method with randomized block design based on the initial body weight of rabbits. The treatment given is the level of use of the best fermented rumen contents in a complete feed ration. Variable which is translated as feed consumption, body weight gain and feed conversion. Research results The first stage of the P4 study sample (72 hours) as the best guideline is seen from the parameters of crude protein and crude fiber. The results of this study indicate that the use of feed using rumen 
fermentation (IRF) can increase feed consumption and weight gain. The conclusion of this study is the provision of $30 \%$ mixture of fermented rumen contents of Cellulomonas $\mathrm{sp}$ in complete feed produced the best results seen from the parameters of consumption, weight gain and feed conversion of rabbit.

Keywords: Rumen contents, fermentation, Cellulomonas sp, complete feed, rabbits

\section{PENDAHULUAN}

Kegiatan usaha peternakan seperti pemeliharaan ternak, rumah potong hewan (RPH) ataupun pengelolaan produk ternak akan menghasilkan sisa buangan yang merupakan limbah ternak, dimana semakin berkembangnya suatu usaha peternakan maka limbah yang dihasilkan akan semakin meningkat. Pengolahan limbah ternak diharapkan dapat mengurangi pencemaran lingkungan dan memperoleh keuntungan. Pengolahan limbah dapat dilakukan dengan cara menggunakan limbah ternak sapi sebagai pupuk kandang untuk tanaman, sebagai penghasil biogas, bioarang dan campuran bahan pakan ternak (Junus 2011).

Konsumsi minimal protein hewani masyarakat Indonesia oleh Organisasi Pangan dan Pertanian Dunia, direkomendasikan sebanyak 6 g/kapita/hari tetapi sampai saat ini konsumsi protein tersebut masih dibawah standar yaitu 4,19 g/kapita/hari. Untuk mencapai target tersebut maka pemerintah berusaha memperbaiki dan mengembangkan sub sektor peternakan tersebut dimana salah satu komoditas penghasil protein hewani yang cukup potensial dikembangkan adalah ternak kelinci. Kelebihan ternak kelinci sebagai penghasil daging adalah kualitas dagingnya baik, yaitu kadar proteinnya tinggi $21 \%$, kalori $160 \mathrm{kkal}$, lemak 8\%, air $70 \%$ dan kolesterol $71 \mathrm{mg}$ (Dirjen Peternakan dan Kesehatan Hewan, 2011), Berdasarkan data Direktorat Jenderal Peternakan Departemen Pertanian (2014), jumlah sapi potong yang dipotong setiap tahun tidak kurang dari 1,75 juta ekor, sekitar 1,5 juta ekor berasal dari sapi sapi lokal dengan berat rata rata $300 \mathrm{~kg}$ dan sisanya adalah sapi sapi impor. Berat isi rumen sapi adalah sekitar 14,3\% dari berat sapi (Hungate, 1968), maka dari seekor sapi akan dihasilkan sekitar 42,9 $\mathrm{kg}$ isi rumen sapi. Dengan demikian jumlah isi rumen sapi yang berasal dari sapi yang dipotong di Indonesia mencapai 75,075 ribu ton per tahun. Jumlah cairan rumen mencapai 31 liter per ekor (Priego et al., 1977) sehingga jumlah cairan rumen mencapai 54,25 juta liter per tahun di Indonesia. Jumlah isi dan cairan rumen yang berasal dari sapi sapi potong tersebut sangat besar dan bila tidak ditangani dengan baik dapat mencemari lingkungan. 
Isi rumen memiliki kandungan zatzat gizi yang tinggi, hal ini dikarenakan isi rumen merupakan bahan pakan yang sudah tercerna tetapi belum sempat dimanfaatkan oleh ternak dan bahan pakan ini sangat diperlukan untuk kelangsungan hidup mikroba rumen (Priyanto, 2008). Komposisi zat-zat gizi isi rumen adalah $12,5 \%$ bahan kering, $8,1 \%$ protein kasar, $38,02 \%$ serat kasar, $0,37 \%$ kalsium, $0,26 \%$ posfor dan $2.361 \mathrm{kkal} / \mathrm{kg}$ energi metabolis. Namun demikian limbah tersebut mempunyai faktor pembatas dalam pemanfaatannya sebagai pakan ternak, salah satunya adalah faktor kandungan lignoselulosa yang cukup tinggi sehingga kecernaannya rendah dan dalam keadaan segar masih mengandung mikroba pathogen (Adeniji et al., 2015)

Upaya pemanfaatan isi rumen sapi diperlukan teknologi pengolahan pakan yang mampu merombak senyawa organik kompleks menjadi senyawa yang lebih sederhana sehingga dapat dicerna dengan baik oleh ternak. Berdasarkan hal tersebut, maka penelitian ini dilakukan untuk melihat pemanfaatan isi rumen sapi dengan menggunakan teknik pengolahan fermentasi sehingga memungkinkan isi rumen tersebut dijadikan sebagai pakan ternak kelinci.

\section{MATERI DAN METODE PENELITIAN}

Pada penelitian ini akan dilakukan percobaan uji isi rumen menggunakan Cellulomonas sp dengan lama inkubasi yang berbeda. Penelitian selanjutnya yaitu uji biologis pakan perlakuan yang diformulasi dalam campuran pakan komplit untuk ternak kelinci.

Rangkaian Penelitian ini secara lengkap dapat dijelaskan sebagai berikut:

\section{Penelitian Tahap Pertama}

Penelitian ini bertujuan untuk mengetahui lama inkubasi yang menghasilkan kandungan nutrisi terbaik melalui proses fermentasi dengan Cellulomonas sp pada isi rumen. Penelitian ini dilakukan dengan melakukan pengambilan sampel isi rumen dari $\mathrm{RPH}$ (Rumah Pemotongan hewan). Sampel tersebut kemudian dikeringkan dan diberi perlakuan fermentasi dengan tambahan Cellulomonas sp. Alat yang digunakan antara lain timbangan $O$ 'haus serta wadah tempat fermentasi, seperangkat alat analisis proksimat. Penelitian ini menggunakan metode eksperimental dengan rancangan acak lengkap (RAL) empat perlakuan dan enam ulangan. Perlakuan dibagi berdasarkan lama fermentasi terhadap isi rumen yang terdiri dari 0 jam, 24 jam, 48 jam, 72 jam. Peubah yang diamati pada tahap ini terdiri dari protein kasar (AOAC, 2005) dan serat kasar (AOAC, 2005). 


\section{Penelitian Tahap Kedua}

Tahapan ini merupakan kelanjutan dari penelitian I. Penelitian ini bertujuan untuk mempelajari aplikasi penggunaan produk fermentasi limbah ternak sapi berupa isi rumen sebagai penyusun pakan komplit terhadap penampilan kelinci. Penelitian ini menggunakan tiga puluh enam ekor kelinci lokal lepas sapih, produk pakan limbah ternak sapi (isi rumen) terbaik dari penelitian pertama serta bahan campuran pakan lainnya meliputi jagung, bungkil kedelai, bekatul, mineral dan hijauan. Kandang dan perlengkapan kandang tempat pakan dan tempat minum, timbangan duduk, thermometer ruang, oven untuk pengeringan sampel untuk dianalisis kandungan nutrien. Penelitian ini menggunakan metode eksperimental dengan rancangan acak kelompok berdasarkan bobot badan awal dari kelinci. Kelinci yang digunakan diperoleh dari peternakan kelinci milik peternak Kota Manado dan sekitarnya. Pakan perlakuan terdiri dari lima level yang diulang pada tiga kelompok bobot badan, setiap unit percobaan diisi dua ekor kelinci jantan sehingga jumlah kelinci yang digunakan sebanyak tiga puluh ekor. Perlakuan yang diberikan adalah level penggunaan isi rumen terfermentasi terbaik dalam ransum pakan komplit dengan susunan sebagai berikut:
- $\quad$ R0 = Ransum tanpa menggunakan Isi rumen

- $\mathrm{R} 1$ = Ransum menggunakan $10 \%$ isi rumen fermentasi

- $\quad$ R2 = Ransum menggunakan $20 \%$ isi rumen fermentasi

- $\quad$ R3 = Ransum menggunakan 30\% isi rumen fermentasi

- $\quad$ R4 = Ransum menggunakan $40 \%$ isi rumen fermentasi

Peubah yang diamati pada penelitian tahapan ini terdiri dari konsumsi pakan (g/ekor), Pertambahan bobot badan (g/ekor) dan konversi pakan.

\section{Pelaksanaan Penelitian in vivo}

Pelaksanaan penelitian ini dibagi menjadi 2 tahap sebagai berikut:

\section{Tahap persiapan}

- Memilih kelinci dengan menimbang bobot badan awal kelinci dengan cara penimbangan 2 hari pertama berurutan, diseleksi bobot badan kelinci menjadi tiga kelompok bobot badan: kecil, sedang dan besar

- Semua kelinci yang sudah terseleksi dimasukkan dalam kandang battery dan penempatan unit percobaan diatur dengan cara undian dan setiap unit percobaan diisi tiga ekor kelinci.

- Setelah ternak masuk kandang percobaan, lalu diadaptasikan dengan pakan perlakuan dengan masa adaptasi berlangsung antara 5-10 hari. 
- Membuat perhitungan kebutuhan masing masing bahan pakan sesuai dengan formulasi untuk pakan perlakuan.

\section{Tahap Pendahuluan dan Koleksi Data}

Pendahuluan. Semua ternak percobaan diberi pakan perlakuan sebanyak 3 kali setiap hari pada pukul 07.00 WITA, 12.00 WITA dan pukul 17.00 WITA. Kegunaan penelitian pendahuluan ini untuk menghilangkan pengaruh pakan sebelumnya serta menentukan jumlah pemberian pakan, kegiatan ini dilakukan selama 5 - 10 hari.

Koleksi data. Jumlah pakan perlakuan disiapkan sehari sebelum pemberian sedangkan penimbangan sisa pakan pada pagi hari berikutnya pukul 06.30 sampai 07.00 WITA, masing masing sisa pakan dikumpulkan pada tempat yang ditentukan.

\section{Analisis Statistik}

Data yang diperoleh ditabulasi dengan menggunakan program excel untuk dianalisis menggunakan sidik ragam dengan Rancangan Acak Kelompok (RAK). Apabila analisis sidik ragam menunjukkan perbedaan yang nyata maka akan dilanjutkan dengan uji Duncan. Model matematik untuk analisis data menurut petunjuk Yitnosumarto (1993),

$$
Y i j=\mu+T i+\beta j+€ i j
$$

Keterangan :
Yij = Nilai pengamatan perlakuan ke $\mathrm{i}$ kelompok ke j

$\mu \quad=$ Nilai tengah umum

$\mathrm{Ti}=$ Pengamatan perlakuan ke $\mathrm{i}$

$\mathrm{Bj} \quad=$ Pengaruh kelompok ke $\mathrm{j}$

$€ \mathrm{ij} \quad=$ Galat percobaan pada perlakuan ke i, kelompok ke j

\section{HASIL DAN PEMBAHASAN}

\section{Pengaruh Lama Inkubasi terhadap Kandungan Protein dan Serat Kasar Isi Rumen terfermentasi Cellulomonas $S p$}

Hasil percobaan pengaruh lama inkubasi terhadap kandungan protein dan serat kasar isi rumen terfermentasi Cellulomonas $S p$ dapat dilihat pada tabel di bawah. Hasil analisis ragam menunjukkan bahwa perlakuan lama inkubasi memberikan pengaruh sangat nyata $(\mathrm{P}>0,01)$ terhadap kandungan protein dan serat kasar. Adapun hasil uji lanjut dengan DMRT (Duncan's Multiple Range Test), rataannya tampak seperti pada Tabel 1. Berdasarkan Tabel 1 dapat dilihat bahwa kandungan protein dari limbah ternak sapi (isi rumen) yang diinkubasi pada lama inkubasi yang berbeda, ternyata mengalami penurunan pada hari pertama (24 jam) dan kenaikan pada hari kedua (48 jam) sampai dengan hari ketiga (72 jam). Rataan kandungan protein pada perlakuan $0,24,48$ dan 27 jam, berturut-turut adalah 8,17\%, $8,52 \%, 9,66 \%$ dan $9,26 \%$. 
Tabel 1. Pengaruh lama inkubasi terhadap kandungan protein dan serat kasar

\begin{tabular}{lcccc}
\hline \multirow{2}{*}{ Kandungan Zat Makanan } & \multicolumn{4}{c}{ Perlakuan/ Lama Inkubasi } \\
\cline { 2 - 5 } & P1 (0 Jam) & P2 (24 Jam) & P3 (48 Jam) & P4 (72 Jam) \\
\hline Protein (\%) & $8,17^{\mathrm{a}}$ & $8,52^{\mathrm{a}}$ & $9,66^{\mathrm{b}}$ & $9,26^{\mathrm{b}}$ \\
Serat Kasar (\%) & $37,1^{\mathrm{b}}$ & $36,72^{\mathrm{b}}$ & $32,49^{\mathrm{a}}$ & $35,83^{\mathrm{c}}$ \\
\hline
\end{tabular}

Keterangan: huruf yang berbeda pada baris yang sama menunjukkan perbedaan yang sangat nyata $(\mathrm{P}<0,01)$

Diduga mikroorganisme yang dapat merombak asam amino pada proses inkubasi berasal dari mikroorganisme yang terdapat dalam isi rumen yaitu salah satunya adalah bakteri proteolitik. Soetanto (2011) dan Bhatt et al. (2017) menyatakan bahwa bakteri proteolitik merupakan jenis bakteri yang banyak terdapat pada saluran pencernaan mamalia, dimana beberapa spesies bakteri protolitik diketahui menggunakan asam amino sebagai sumber energi utama energi.

Berdasarkan Tabel 1 diatas maka dapat dilihat juga bahwa lama inkubasi memberikan pengaruh sangat nyata $(\mathrm{P}<0,01)$ tehadap kandungan serat kasar limbah ternak sapi yaitu isi rumen. Semakin tinggi waktu inkubasi maka kandungan serat kasar limbah ternak sapi semakin rendah. Adapun rataan lama inkubasi 0, 24, 48 dan 72 jam yaitu 37,1\%, 36,72\%, $32,49 \%$ dan 35,83\%. Hasil uji lanjut Duncan menunjukkan bahwa lama inkubasi 48 jam memberikan hasil terbaik kandungan serat kasar pada limbah ternak sapi tersebut.

Penurunan kandungan serat kasar ini disebabkan karena semakin lama fermentasi maka akan semakin lama pula mikroorganisme yang terdapat pada limbah ternak sapi tersebut dalam hal ini isi rumen mendegradasi senyawa kompleks serat kasar menjadi lebih sederhana (Soetanto, 2011). Ghunu et al. (2010) menyatakan bahwa penurunan serat kasar terjadi karena dengan bertambahnya lama inkubasi, spora-spora miselium semakin banyak pada saat terjadinya kolonisasi. Seiring dengan hal itu, produk enzim selulase yang dihasilkan juga semakin banyak. Akibatnya, pada waktu yang bersamaan terjadi degradasi serat kasar yang semakin tinggi pula sehingga menyebabkan kandungan serat ikut menurun. Moningkey et al. (2016) juga menyatakan bahwa selama biokonversi, mikroba menghasilkan enzim selulolitik yang menguraikan selulosa menjadi glukosa, menyebabkan 
Tabel 2. Rataan konsumsi, PBB dan konversi pakan kelinci selama penelitian

\begin{tabular}{lccccc}
\hline $\begin{array}{l}\text { Variabel } \\
\text { (g/ekor/hari) }\end{array}$ & $\mathrm{R} 0$ & $\mathrm{R} 1$ & $\mathrm{R} 2$ & $\mathrm{R} 3$ & $\mathrm{R} 4$ \\
\cline { 2 - 6 } Konsumsi Pakan & $59,67^{\mathrm{ab}}$ & $59,82^{\mathrm{ab}}$ & $64,34^{\mathrm{ab}}$ & $65,82^{\mathrm{b}}$ & $57,85^{\mathrm{a}}$ \\
PBB & $14,67^{\mathrm{ab}}$ & $15,13^{\mathrm{ab}}$ & $16,23^{\mathrm{ab}}$ & $19,57^{\mathrm{b}}$ & $13,13^{\mathrm{a}}$ \\
Konversi & 4,06 & 3,95 & 3,96 & 3,36 & 4,40 \\
\hline
\end{tabular}

Keterangan : Huruf yang berbeda pada kolom yang sama menunjukkan perbedaan sangat nyata $(\mathrm{P}<0.01)$

substansi organik dalam hal ini selulosa dan hemiselulosa berkurang. Bedasarkan hasil penelitian ini terlihat bahwa semakin tinggi lama inkubasi maka komponen serat kasar yang dirombak semakin tinggi, sehingga mengakibatkan fraksi serat kasar menurun.

\section{Pengaruh Penggunaan Isi Rumen Terfermentasi Cellulomonas $S p$ dalam Pakan Lengkap terhadap Konsumsi Pakan}

Hasil percobaan penggunaan Isi rumen terfermentasi Cellulomonas $S p$ dalam pakan komplit terhadap penampilan produksi ternak kelinci dapat dilihat pada lampiran Tabel 2. Salah satu faktor penting untuk menentukan produktivitas ternak yaitu jumlah pakan yang dikonsumsi (Sampul et al., 2018; Khan et al., 2017). Rataan konsumsi pakan kelinci selama penelitian ditampilkan pada Tabel 2. Hasil penelitian menunjukkan bahwa konsumsi ransum paling tinggi terlihat pada perlakuan R3 yaitu 65,82 g/ekor/hari. Perlakuan R3 secara statistik sangat nyata lebih tinggi $(\mathrm{P}<0,01)$ dibandingkan dengan perlakuan R0, R1 dan R4 masing masing dengan nilai 59,67 g/ekor/hari, 59,82 g/ekor/hari dan 57,85 g/ekor/hari tetapi tidak berbeda nyata dibandingkan dengan perlakuan R2 dengan nilai dan 64,34 g/ekor/hari.

Hasil percobaan menunjukkan bahwa pemberian pakan yang menggunakan isi rumen fermentasi (IRF) dapat meningkatkan konsumsi sampai dengan pemberian $30 \%$ dan selanjutnya akan menurunkan konsumsi ransum pada pemberian $40 \%$. Hal ini berarti penggunaan isi rumen fermentasi dalam pakan lengkap dapat memacu nafsu makan kelinci sampai dengan penggunaan $30 \%$ yang mungkin disebabkan produk fermentasi mengandung hasil sintesa vitamin B komplek yang dapat meningkatkan nafsu makan. Hasil penelitian dari Moningkey et al. (2016) menyatakan bahwa salah satu manfaat fermentasi adalah meningkatkan kualitas serta palatabilitas pakan. Wuysang et al. 
(2017), menyatakan bahwa terdapat beberapa faktor yang mempengaruhi tingkat konsumsi ternak baik dari faktor internal ataupun faktor eksternal yaitu temperatur lingkungan, palatabilitas, selera, status fisiologis, konsentrasi nutrisi, bentuk pakan dan bobot badan dari ternak. Selanjutnya Church and Pond (1980) menyatakan bahwa palatabilitas suatu pakan berhubungan dengan tekstur, warna, rasa dan bau pakan tersebut.

\section{Pengaruh Penggunaan Isi Rumen Terfermentasi Cellulomonas $S p$ dalam Pakan Lengkap terhadap Pertambahan Bobot Badan}

$\begin{array}{ccr}\text { Hasil } & \text { analisis } & \text { ragam } \\ \text { memperlihatkan } & \text { bahwa perlakuan }\end{array}$
pemberian isi rumen terfermentasi dalam pakan komplit menunjukkan perbedaan sangat nyata $\quad(\mathrm{P}<0,01) \quad$ terhadap pertambahan bobot badan ternak kelinci. Adapun rataan dari pertambahan bobot badan ternak kelinci tampak pada Tabel 2 . Pertambahan bobot badan paling tinggi terdapat pada perlakuan R3 yaitu 19,57 g/ekor/hari. Perlakuan R3 sangat nyata lebih tinggi $(\mathrm{P}<0,01)$ dari perlakuan $\mathrm{R} 0$, $\mathrm{R} 1, \mathrm{R} 2$ dan R4 masing masing dengan nilai 14,61 g/ekor/hari, 15,13 g/ekor/hari, 16,23 g/ekor/hari dan 13,13 g/ekor/hari.

Perlakuan R3 merupakan perlakuan terbaik yang menghasilkan pertambahan bobot badan tertinggi dibandingkan dengan perlakuan R0, R1, R2 dan R4. Perlakuan R3 juga menunjukkan jumlah konsumsi tertinggi selama penelitian dibandingkan dengan perlakuan lain sehingga perlakuan R3 juga menghasilkan pertambahan bobot badan yang tertinggi pula. Hal ini mengindikasikan bahwa pemberian $30 \%$ campuran isi rumen terfermentasi Cellulomonas sp dalam pakan komplit menunjukkan hasil pertambahan bobot badan terbaik dibandingkan dengan perlakuan lainnya.

Rasyid (2009) dan Pasupathi et al. (2015) menyatakan bahwa salah satu faktor yang mempengaruhi pertambahan bobot badan adalah konsumsi pakan. konsumsi pakan dan kecernaan pakan yang tinggi akan menghasilkan pertambahan bobot badan yang lebih tinggi. Hal ini disebabkan oleh semakin banyak nutrien yang diserap oleh tubuh ternak tersebut. Selanjutnya Rumondor et al. (2019) menyatakan bahwa bobot badan ternak berbanding lurus dengan tingkat dari konsumsi pakannya. Hal itu berarti bahwa konsumsi pakan akan memberikan gambaran nutrien yang didapat oleh ternak sehingga mempengaruhi pertambahan bobot badan ternak. Menurut Scott et al. (1982) menyatakan bahwa terdapat hubungan yang erat antara pertumbuhan dengan konsumsi pakan. Konsumsi pakan yang semakin tinggi akan mengakibatkan kenaikan konsumsi protein sehingga pertumbuhan 
ternak semakin baik dan akan meningkatkan bobot potong yang dihasilkan. Konsumsi pakan yang relatif sama antar perlakuan akan mengakibatkan nutrien yang dikonsumsi sama dimana nutrien tersebut digunakan untuk mencukupi kebutuhan hidup pokok dan pertumbuhan organ serta jaringan tubuh.

\section{Pengaruh Penggunaan Isi Rumen Terfermentasi Cellulomonas sp dalam Pakan Lengkap terhadap Konversi Pakan}

Berdasarkan Tabel 2 terlihat bahwa rataan konversi pakan berturut turut yaitu 4,06 (R0), 3,95 (R1), 3,96 (R2), 3,36 (R3) dan 4,40 (R4). Perlakuan R3 menunjukkan nilai konversi pakan terendah meskipun secara statistik tidak berbeda nyata ( $\mathrm{P}>0,05)$ dibandingkan dengan perlakuan R0, R1, R2 dan R4. Semakin rendah angka konversi pakan suatu perlakuan menunjukkan bahwa kualitas pakan semakin efisien. Perlakuan R3 menunjukkan nilai konversi terendah dibandingkan dengan perlakuan lainnya dalam penelitian ini. Hal ini menunjukkan bahwa perlakuan R3 lebih efisien dibandingkan perlakuan yang lain. Rataan nilai konversi pakan kelinci selama penelitian diperoleh sekitar 3,60. Artinya untuk mendapatkan pertambahan bobot badan $1 \mathrm{~kg}$ membutuhkan pakan sebanyak 3,60 kg. Sedangkan dalam penelitian
Aritonang et al. (2014) konversi ransum antar perlakuan berkisar 2,62 hingga 3,46 dengan rataan 3,00 dengan kandungan nutrisi PK 16\%, DE $2500 \mathrm{kkal} / \mathrm{kg}$ dan 0,1\% biovet. Semakin rendah nilai konversi pakan maka semakin tinggi nilai efisiensi pakan dan berpengaruh pada biaya produksi ternak yang efisien. Konversi pakan dipengaruhi beberapa faktor yaitu genetik, bentuk pakan, temperatur, lingkungan, konsumsi pakan, berat badan, dan jenis kelamin (Fadare 2015). Selanjutnya Maidala et al. (2016) menyatakan bahwa konversi pakan dipengaruhi oleh konsumsi bahan kering dan pertambahan bobot badan harian ternak akan menghasilkan pertambahan bobot badan lebih tinggi dan lebih efisien penggunaan pakannya.

\section{KESIMPULAN}

Pemberian $30 \%$ campuran isi rumen terfermentasi Cellulomonas sp dalam pakan komplit menunjukkan hasil terbaik dilihat dari parameter konsumsi, pertambahan bobot badan serta konversi ransum ternak kelinci.

\section{DAFTAR PUSTAKA}

Adeniji, A.A., S. Rumak, and R. A. Oluwafemi. 2015. Effects of replacing groundnut cake with rumen content supplemented with or without 
enzyme in the diet of weaner rabbits. Journal Lipids Health 14: 164

Aritonang, D., M. A. Harahap dan Y. C. Raharjo. 2014. Pengaruh penambahan biovet dalam ransum dengan berbagai kandungan protein energi terhadap pertumbuhan anak kelinci Rex. Media Peternakan 20(2): 69-76.

Bhatt, R. S., A.R. Agrawal, A. Sahoo. 2017. Effect of probiotic supplementation on growth performance, nutrient utilization and carcass characteristics of growing Chinchilla rabbits. Journal of Applied Animal Research 45(1): 304-309

Church, D.C. dan W.G. Pond. 1980. Basic Animal Nutrition and Feeding. 3rd ed Jhon Willey and Sons. New York

Direktorat Jenderal Peternakan dan Kesehatan Hewan, 2011. Pedoman Pelaksanaan Kampoeng Kelinci. Direktorat Budidaya Ternak, Direktorat Jenderal Peternakan dan Kesehatan Hewan, Kementerian Pertanian, Jakarta

Ditjen Peternakan Deptan, Direktorat Jenderal Peternakan Departemen Pertanian. 2014. Statistik Peternakan 2013. http://www.ditjenak.go.id [23 Oktober 2019]

Fadare, A.O. 2015. Feed utilization of New Zealand white, Californian, Palomino brown and Havana black rabbit in the humid tropics. Sky Journal of Agricultural Research 4(2): 38 - 41

Hungate, R. E. 1968. The Rumen and it's Microbes. New Jersey. Academic Press.

Junus, M. 2011. Akselerasi Pembangunan Unit Gas Bio Untuk Pengembangan Aneka Ternak Di Indonesia. Pidato Pengukuhan Jabatan Guru Besar dalam Bidang Ilmu Produksi Aneka Ternak pada Fakultas Peternakan Universitas Brawijaya. Disampaikan pada Rapat Terbuka Senat Universitas Brawijaya Malang.

Khan, K., S. Khan, N. A. Khan dan N. Ahmad. 2017. Production performance of indigenous rabbits under traditionaland intensive production systems in Northern Pakistan. The Journal of Animal \& Plant Sciences 27(1): 75-81

Maidala, A., T. N. Dahuwa, S. Bakoji, I.B. Bello, dan D.T. Ajighjigh. 2016. Growth Performance and carcass characteristics of rabbits fed differently processed soybean. Journal of Biology and Genetic Research 2(1): 9-14.

Moningkey, S., M. Junus, O. Sjofjan, E. Widodo. 2016. Nutritive value evaluation on rumen content ang sludge fermented with Cellulomonas $\mathrm{Sp}$ as rabbit feed. International Journal of Cemtech Research 09(4): 650-656.

Pasupathi, K., H. Gopi, M. Babu, P. Muthusamy. 2015. Growth performance of rabbits on tree leaves included complete extruder feed. World's Veterinary Journal World Vet J. 5(2): 19-22.

Priego, A., A. Wilson, T. M. Sutherland. 1977. The effect on parameters of rumen fermentation, rumen volume and fluid rate of zebu bulls given chopped sugar cane supplemented with rice polishings or cassava root meal. Trop. Anim. Prod. 2: 292-299.

Priyanto, A. 2008. Pemanfaatan limbah biogas sebagai pengganti pakan pellet komersial untuk meningkatkan pertumbuhan benih dan perkembangan kematangan gonad 
lele dumbo (Clarias gariepinus). Skripsi Fakultas Perikanan Universitas Brawijaya Malang.

Rumondor, A.R.P., B. Tulung., A. Rumambi., C.A. Rahasia. 2019. Pengaruh penggantian jagung dengan sorgum $\mathrm{Cv}$. Kawali dalam ransum pellet terhadap performans kelinci lokal. Jurnal Zootec 39(1): $42-50$

Rasyid, H. 2009. Performa Produksi Kelinci Lokal Jantan Pada Pemberian Rumput Lapang Dan Berbagai Level Ampas Tahu. Skripsi. Fakultas Peternakan. Institut Pertanian Bogor, Bogor.

Sampul, M. B., B. Tulung, J. F. Umboh, S. A. E. Moningkey. 2018. Pengaruh pemanfaatan daun ubi jalar (Ipomea Batatas L) terhadap performans ternak kelinci. Jurnal Zootec 38(2): $314-319$.

Scott, M.L., M.C. Nesheim, dan R.J. Young. 1982. Nutrition of the Chicken. 3nd Ed. ML Scott and Association Ithaca, New York

Soetanto. 2011. Teknologi Pemanfaatan Mikroorganisme Dalam Pakan Untuk Meningkatkan Produktivitas Ternak Ruminansia Di Indonesia. Balai Penelitian Ternak. Bogor. http://peternakan.litbang.depta n.go.id/fullteks/wartazoa/wazo1542.pdf [2 November 2019]

Wuysang, S., C.A. Rahasia, J.F. Umboh, Y. L. R. Tulung. 2017. Pengaruh penggunaan molases sebagai sumber energi pakan penguat dalam ransum terhadap pertumbuhan ternak kelinci. Jurnal Zootec 37(1): $149-155$
Yitnosumarto, S. 1993. Perancangan Percobaan, Analisis, dan Interpretasinya. PT. Gramedia Pustaka Utama. Jakarta. 